\title{
UUSLIBERALISMI KUIN YHDEKSÄNHENKINEN KISSA JA SOSIAALISEN KYSYMYKSEN RATKAISEMINEN
}

\author{
Briitta Koskiaho: sosiaalipolitiikean professori emerita, Tampereen yliopisto
}

briitta.koskiabo@tuni.fi

Janus vol. 29 (4) 2021, 386-397

Analysoin angloamerikkalaisen uusliberalismin ydintarinan brittiläistä muotoa ja kehitystä suhteessa sosiaalisen kysymyksen ratkaisemiseen. Matkaa tehdään tutkimusprojektieni tulosten valossa 1990-luvulta alkaen.

Uusliberalismi ja sosiaalipolitiikka sopivat jo käsitteellisesti huonosti yhteen. Taloudellinen valta on pyrkinyt vähentämään valtion, sosiaalipolitiikan pystyssäpitäjän, merkitystä ja edistämään omaa toimintaansa. Uusliberalismin ydinkysymys liittyy yksityisen talouden ja valtion, julkisen hallinnon, välisen suhteen muovautumiseen. Sosiaalipolitiikan ja hyvinvointivaltion kaari liittyy elimellisesti tähän yhteyteen. Sosiaalipolitiikan ydin on saksalaisen 1800-luvun lopun muotoilun mukaan sosiaalisen kysymyksen hoitamisessa. Sosiaalisen kysymyksen valtion ohjaama ja tukema institutionaalinen hoito on ollut koetuksella Euroopassa 1980-luvulta lähtien.

Pohdintani kohdistuu myös kysymykseen uusliberalismin mahdollisesta häviämisestä, kuolemasta, joka on ollut tutkijoiden keskustelun aiheena entistä useammin viime aikoina. Koronapandemia näyttää kiihdyttäneen tämänkin aiheen käsittelyä. Se, mitä tapahtuu sosiaalipolitiikalle tulevaisuudessa, askarruttaa monen mieltä juuri nyt.

\section{UUSLIBERALISMI, SEN YDIN JA MONIMUOTOISUUS}

Uusliberalismi on kuin kissa, jolla on yhdeksän henkeä ja yhdeksän elämää. Näin sitä luonnehtivat tutkijat Quinn Slobodian, Dieter Plewne ja Philip Mirowski (2020). Yhdysvaltojen ja IsonBritannian johtajat Ronald Reagan ja Margaret Thatcher löivät kättä päälle 1970- ja 1980-luvun vaihteessa innoissaan uudesta yhteisestä talouspoliittisesta suunnasta, jonka avulla alettiin kilpailuttaa ja yksityistää julkisia toimintoja Britanniassa. Aluksi kohteena olivat valtionrautatiet. Rautatielinjoja jaettiin kilpailuttaen yksityisille toimijoille. Näkyvä manifestaatio koski läheisesti matkustajia ja koko kansaa. Tämän jälkeen myös sosiaalipolitiikka joutui samantapaisten muutosten kohteeksi.

Uusliberalismin poliittinen toteuttaminen Euroopassa angloamerikkalaisen mallin mukaan on noin neljäkymmentä vuotta vanha. Se on jo paljon, koska yhteiskunnallisten virtausten arvioidaan yleensä elävän noin kolmekymmentä vuotta. Uusliberalismin politiikassa on kyse yksityisen taloussektorin ja julkisen sektorin uudelleenmuotoilusta. Julkinen sektori myötäilee ja tukee yksityisen talouden pyrkimyksiä. Aiemmin pyrittiin minimoimaan koko julkinen sektori, myöhemmin enemmän muo- 
vailemaan sen sisältöä yritysmäiseksi ja siirtämään toimintoja yksityisen sektorin järjestämiksi, markkinoille, erilaisin järjestelyin (Kotz 2015).

Uusliberalismi ei kuitenkaan syntynyt brittiyhteiskunnassa vaan Keski-Euroopassa. Saksassa uusliberalismin menestyksellisin muoto on ollut ordoliberalismi ja sen sosiaalimarkkinasuuntaus, joka on vaikuttanut voimallisesti saksalaiseen politiikkaan toisen maailmansodan jälkeisenä aikana (Koskiaho 2018). Uusliberalismin juuret ovat klassisessa liberalismissa, jonka edustajat lähtivät vastustamaan 1600-luvun merkantilistista talouspolitiikkaa ja taloudellista valtaa, joka oli säätyjen käsissä. Erityisesti käsityöläiset halusivat saada oikeudet harjoittaa elinkeinoaan vapaasti. Tästä syntyi liberalismin taloudellisen vapauden teesi. Sitten valistusaika toi esille kansalaisuuden ja kansalaisoikeudet, taloudellisten oikeuksien lisäksi myös poliittiset ja sosiaaliset kansalaisoikeudet. Uusliberalismin eurooppalaiset esitaistelijat ja kehittäjät Saksassa painottivat 1920-luvulla taloudellisten oikeuksien merkitystä, vapautta harjoittaa elinkeinoa ja sen mahdollisimman vähäistä valtion sääntelyä.

Uusliberalismin synty on nähtävä vastapainona vanhoille aikojen kuluessa syntyneille instituutioille ja sääntelymekanismeille, joiden takana oli kuningasvalta säätyineen. Ensimmäisen maailmansodan jälkeen kuningasvalta oli jo hellittänyt otettaan maasta toiseen ja tilalle oli tullut parlamentarismi omine instituutioineen ja sääntelymekanismeineen. Liberalismin uudet edustajat, intellektuellit, alkoivatkin kehitellä taloudellisen toiminnan ja sääntelyjärjestelmien välistä suhdetta uudelleen perustuen vapaaseen kilpailuun yksityisillä markkinoilla varsinkin heti toisen maailmansodan jälkeen.Valtion sääntelyvoimaa tulisi alentaa niin paljon kuin mahdollista taloudellisten toimijoiden vapauksiin nähden. Uusliberalismin kehittäjistä osa siirtyi Saksasta kehittämään ideoitaan Brittein saarille ja USA:han natsihallinnon tultua ja uusliberalismin kehittelyn katketessa. Sodan jälkeisenä aikana uusliberalismin kehittely oli Euroopassa intellektuellien varassa vuosikymmeniä aina 1970-luvun taloudellisiin kriiseihin asti, minkä jälkeen uusliberalistiset opit on otettu käyttöön maasta toiseen.

Tämän vuosituhannen kuluessa uusliberalismia on alettu yhä kiihkeämmin povata kuolleeksi, mutta se on herännyt henkiin viimeisimmästäkin kriisistä eli finanssikriisistä 2007-2008. Voidaan kysyä, onko kysymys enää varsinaisesta uusliberalismista. Kun uusliberalismi muuttaa muotoaan, se ilmestyy näkyviin mitä erilaisimpiin yhteiskunnallisiin toimintoihin, joihin sen ei odottaisi millään tavalla edes kuuluvan, kuten kulttuuriin tai yliopiston tutkimustoimintaan. Se myös kompleksisoituu koko ajan esiintyen hybrideinä ja erilaisina muunnelmina, mutaatioina - "variegated" (Birch \& Mykhenenko 2010). Uusliberalismi myös valloittaa maailmaa tunkeutuen maanosasta toiseen. Se on tunnistettu myös entisten tai nykyisten kommunististen maiden politiikassa, kuten Venäjällä ja Kiinassa. 
VANHOJEN TEOLLISUUSKAUPUNKIEN RESTRUKTURAATIO UUSLIBERALISMIKONKRETIAN ALKUVAIHE

Tutustuin sosiaalipolitiikan tutkijana uusliberalismiin konkreettisesti tutkiessani brittien sosiaalipolitiikkaa ja teollisuuden restrukturaatiota vanhoissa teollisuuskaupungeissa 1990-luvulla niin sanotussa Manchesterit-projektissamme (Doling ym. 1994). Projekti oli monitieteinen ja toteutui vuorovaikutuksessa silloisen Manchesterin yliopiston sosiaalipolitiikan tutkijoiden kanssa. Konkreettisena kohteena oli tehdasteollisuuden vähittäinen alasajo sosiaalisine seurauksineen. Tämä tapahtui 1970-luvulta lähtien brittien suurilla teollisuusalueilla, erityisesti Manchesterissä ja sen ympäristössä, kuten melkein parikymmentä vuotta myöhemmin Suomessa, erityisesti Tampereella ja muilla tehdasteollisuuspaikkakunnilla.

Manchesterissa tapahtui suuria mullistuksia itse kaupungin rakenteessa, sen elinkeinoissa, väestön elinolosuhteissa ja työpaikoissa sekä työväen asuntoalueilla kasvavassa uusköyhyydessä. Taustalla oli sopeutuminen uuteen taloudelliseen ajattelutapaan, joka perustui kilpailun lisääntymiseen, nopeisiin siirtymiin, käytettävissä olevan tehdastyöväestön taitojen vanhentumisen ongelmaan ja uuden koulutetun työvoiman tarpeeseen kaupungin lisääntyviä palvelutyöpaikkoja varten. Taustalla oli myös hallituksen suosima työpaikkojen yksityistämisprojekti. Julkisen sektorin uudistus kohdistui myös sosiaalipolitiikkaan. Sehän oli rakennettu keynesiläistä valtiollista politiikkaa varten. Nyt haluttiin perustettavaksi uusia sosiaalialan yrityksiä. Alalle nousi suuryrityk- siä, jotka alkoivat dominoida syntyviä sosiaalimarkkinoita.

Manchesterin kuuluisiksi tulleet tehdasteollisuusalueet joen partaalla siirtyivät rakennus rakennukselta muihin käyttötarkoituksiin kuten museoiksi tai palveluelinkeinojen taikka pienteollisuutta harjoittavien toimipaikoiksi samalla tavoin kuin Tampereen Tammerkosken rannan tehtaat pienemmässä mittakaavassa noin pari vuosikymmentä myöhemmin. Tyylikkäät punatiilirakennukset muistuttavat huomattavasti toisiaan niin ulkonäöltään kuin entiseltä ja nykyiseltä toiminnaltaankin brittien ja suomalaisten Manchestereissä. Manchesterin kaupungin toimintojen keskipisteiksi muodostuivat enemmän uudet suuret ostoskeskukset ja näihin liittyvät palvelutoiminnat. Tehdasalueet jäivät taka-alalle syrjään kaupunkikuvassa. Tampereella Tammerkosken ympärillä olevat tehtaat ovat jääneet toiminnallisesti uudistettuina kaupungin keskustan olennaisiksi osiksi.

Molemmissa maissa oli vallinnut omistusasumisen kulttuuri. Brittiyhteiskunnassa muutettiin asuntopolitiikan mallia kaupungeissa varsin nopeasti vuokra-asumista suosivaksi. Sama kehitys on tapahtunut Suomessa, mutta vasta vuosikymmenien päästä. Keynesiläisen politiikan valta-aikana 1940-1960-luvuilla oli tärkeää saada brittiväestö pysymään tehdastyössä, jolloin asuntopolitiikalla vaikutettiin tähän - kuten Suomessakin. Sen sijaan uusliberalismin aikana 1970-luvun lopulta alkaen asukkaat irrotettiin pitkäaikaisista työpaikkasidoksistaan. Vuokra-asunnosta on helppo päästä eroon muutettaessa paikkakunnalta toiselle ja etsittäessä parempia elinmahdollisuuksia. Vakauden 
sijasta elämään tuli irrallisuus. Suomessa tämä tapahtui taas viiveellä.

1990-luvulla brittipolitiikassa toimi sekä konservatiivien että Labourpuolueen hallituksia. Suomen kaltaisia koalitiohallituksia ei harrasteta. Juuri ennen vuosisadan vaihtumista valtaa piti Labour-hallitus. Työväenpuolue alkoi harjoittaa niin sanottua kolmannen tien politiikkaa kuten USA:ssa ja Saksassakin tehtiin. Tällä kompromissipolitiikalla pyrittiin lieventämään konservatiivien suosiman talouden ja valtion yhteistoiminnan uusliberalistisuutta. Yksityisen taloussektorin valtaa lievennettiin suhteessa valtioon. Etsittiin keskitietä. Labourin edustajat ymmärsivät, ettei vuosisadan vaihteessa ollut mahdollista palata sosialidemokratian lähellä olevaan keynesiläiseen talouspolitiikkaan. Nyt harjoitettiin politiikkaa, jossa tehtiin myönnytyksiä yhä suurempaan valtaan pyrkivälle yksityiselle taloudelle. Samalla yritettiin ylläpitää sosiaalisia tavoitteita.

Kolmannen tien politiikkakin edisti kuitenkin yksityisen taloudellisen vallan kasvua. Talous sai puhtia myös kansainvälisistä järjestöistä, kuten Maailmanpankista ja Kansainvälisestä valuuttarahastosta, jotka edistivät uusliberalistisia uudistuksia ja talouden globalisaatiota. Tukea tuli myös perustetusta Euroopan Unionista, joka sekin alkoi harjoittaa yksityistä taloutta tukevaa politiikkaa. Sosiaalipolitiikasta muodostettiin entistä enemmän taloutta myötäilevää toimintaa erityisesti työpolitiikassa, jolloin sosiaalisista arvoista tuli välineellisiä. Julkisten menojen karsinnassa auttoi niukkuuspolitiikka erityisesti sosiaaliturvapolitiikassa. Niukkuutta alettiin jakaa brittiyhteiskunnassa aiemmin kuin muualla Euroopassa.

Isossa-Britanniassa, kuten Suomessakin, myös asuinalueisiin suuntautuvaa kansalaisia aktivoivaa tutkimusta, toimintatutkimusta, oli harjoitettu erityisesti 1970-luvulta alkaen myös Manchesterissä, kuten Tampereellakin (Koskiaho 1978). Sitä alettiin suunnata 1990-luvulla taloudellisen kehityksen vastustamiseen tai sen seurausten lieventämiseen. Kansalaisen sosiaalipolitiikka -projektissamme yritimme juuri vuosituhannen vaihtumisen kynnyksellä pohtia kansalaisyhteiskunnan mahdollisuuksia ja vauhdilla kehittyvän palveluyhteiskunnan aiheuttamia muutoksia sosiaalipolitiikkaan (Koskiaho ym. 1999). Kysyimme, mikä on sosiaalinen kysymys tietotekniikan ja talouden globalisoitumisen maailmassa. Sekä Isossa-Britanniassa että Suomessa niin tutkijat kuin kansalaisjärjestötkin sekä osittain myös valtion viranomaiset yrittivät 1990-luvulla valtaistaa kansalaisia, jotta nämä voisivat itse taistella sosiaalisten arvojen ja yhteisöllisyyden puolesta erityisesti omilla asuinalueillaan mutta myös kokonaisyhteiskunnallisesti ja siten lyödä jarruja liian voimakkaaksi koetulle uusliberalistisen talouden dominoimalle kehitykselle yhteiskunnassa.

\section{Hyvinvointipalvelujen tavaratalossa - SYVENEVÄ UUSLIBERALISMI}

Seuraava tapaamiseni brittiläisen uusliberalismin kanssa tapahtui vuosisadan vaihteessa ja sen jälkeen, kun aloin seurata, mitä Ison-Britannian sosiaalipolitiikassa oikein tapahtui yksityistämisen kannalta (Koskiaho 2008). Konkreetti- 
sesti huomiotani alussa kiinnitti muun muassa se, että yksityisiin sosiaalipalvelutyöpaikkoihin alettiin palkata enenevästi maahantullutta työvoimaa brittien sijasta. Työvoimaa saatiin huomattavasti halvemmalla kuin aiemmin. Samalla myös työntekijöiden kokemusja laatutaso alkoivat laskea. Pitkäaikaiset työsuhteet menettivät merkitystään. Suuret konsernit tulivat sosiaalimarkkinoille entistä vahvemmin. Niille kelpasi halpa työvoima kustannusten pitämiseksi alhaalla. Palvelujen kilpailuttaminen systematisoitui entisestään. Vanhat, sairaat ja vammaiset eivät olleet enää varmoja olinpaikkansa ja hoivansa tulevaisuudesta, kun palvelujen tuottaja saattoi parin kolmen vuoden päästä vaihtua toiseen hoivakodeissa ja muissa laitoksissa. Dramaattisista tapauksista raportoitiin tiedotusvälineissä.

Yksityistäminen oli toimintojen ja toimijoiden siirtämistä julkiselta yksityiselle sektorille. Sosiaalipolitiikan hyvinvointipalvelut tavarataloistuivat tai marketisoituivat. Julkisen hallinnon periaatteet muuttuivat. Seurattiin yrityshallinnon ja toiminnan oppeja soveltaen uusliberalistista New Public Management -mallia hallinnon ylätasolta alatasolle asti. Toimintoja yhtiöitettiin, vaikka ne jäivätkin julkiseen omistukseen. Julkista hallintoa virtaviivaistettiin ja tehostettiin pyrkien pois byrokratisoituneen toiminnan hierarkioista ja suhteista. Julkisen hallinnon aiemmat hyveet oikeamielisestä ja oikeudenmukaisesta sekä tasapuolisesta toiminnasta korvautuivat kunkin toimijan taloudellisella vastuulla ja tehokkuusvaatimuksella sekä yksikköjen jatkuvalla raportointivelvollisuudella.
Toisaalta korostettiin vapautta. Sen hintana oli mahdollisimman tehokas ja tuottoisa toiminta tulos tai ulos -mentaliteetin mukaisesti. Aiempi kollektiivinen vastuu muuntui yksilölliseksi vastuuksi. Myös kollektiivisesti määräytyvä palkkaustapa siirtyi yksityisiin neuvotteluihin ja kilpailuun. Brittiyhteiskunnassa ammattiyhdistysliike menetti nopeasti merkityksensä ajaessaan kollektiivisia sopimuksia työnantajien ja -saajien välillä. Kompleksisiin sosiaalisiin tilanteisiin tällainen suoraviivaistaminen tehokkuusvaateineen sopi varsin huonosti. Toisaalta vanhaa hallintoa oli kritisoitu liiasta byrokratisoitumisesta. Työsuhteiden vapauttamisen lisäksi vapaus koski myös asiakkaiden valinnanvapautta tehdä palveluvalintoja. Käytännössä tilanne oli kuitenkin paljon monimutkaisempi erilaisine rajoituksineen.

Kolmannelle sektorille tuli seinä vastaan: joko suostut kilpailtavaksi tai sitten lopetat toimintasi. Kolmas sektori joutui taistelemaan olemassaolostaan ja kehittämään yritystoimintaansa. Sen luonne muuttui. Hengenpitimiksi keksittiin käsite yhteiskunnallinen yritys, jonka pitäisi toimia voitontavoittelun ulkopuolella. Yhteiskunnallisista yrityksistä kasvoi brittiyhteiskunnassa suuryrityksiä, jotka toimivat kuten muutkin yritykset sosiaalimarkkinoilla. Erona muuhun yritystoimintaan oli se, että osa tuotosta piti panna kiertämään yrityksen sisällä tai lahjoittaa se hyväntekeväisyyteen. Idea levisi myös Suomeen, jossa se osittain kuivettui kokoon, kun yritysmuoto siirrettiin osakeyhtiölainsäädännön piiriin. Valtio myötäili yritysmaailman intressejä eikä sosiaalisen maailman etuja kummassakin tapauksessa, Suomessa kuitenkin 
enemmän. Myöhemmin yhteiskunnallisissa yrityksissä alettiin painottaa sosiaalisten tavoitteiden ohella ympäristöllisiä tavoitteita niin brittiyhteiskunnassa kuin Suomessakin (Social Enterprise UK).

Brittiyhteiskunnassa eli tämän vuosituhannen ensimmäisen vuosikymmenen aikana Labour-hallituksen edistämä tavoite siitä, että kaikkien yritysten harjoittamaa sosiaalista toimintaa on pystyttävä tarkkailemaan ja arvioimaan tehokkaasti. Tämän arvioinnin tulokset ovat helposti myös kansalaisten saatavilla. Niinpä kehitettiin innolla yksityisten toimijoiden, erityisesti hoivakotien, varsin pitkälle menevää tarkkailua ja arviointia, jonka yksityiskohtaiset ja ajankohtaiset tulokset kustakin kohteesta olivat kaikkien luettavissa netistä. Hoivakodit jakautuvat sen mukaan, onko niissä itse maksavia vai tulokynnyksen alittavia valtion maksamia asukkaita vaiko molempia. Arviointitoimintaa sovellettiin kaikkiin. Kansalaiset saattoivat tehdä luotettavia hakupäätöksiä käyttäen vertailuja. Kun konservatiivit tulivat hallitusvaltaan vuonna 2010, alettiin siirtyä omavalvontaan. Yritystoiminnan ulkopuolinen yksityiskohtainen tarkkailu ei ollut uusliberalistisen politiikan mukaista. Se oli liian kallista. Omavalvonta sopii ainoana metodina hauraiden asukkaitten tai potilaiden olosuhteiden tarkkailuun erittäin huonosti. Tässäkin uusliberalistisessa suuntauksessa Suomi on täydellisesti omaksunut samat ideat. Omavalvonta on kunniassa ja julkisen hallinnon valvontaresurssit ovat riittämättömät muuhun valvontaan.

Hyvinvointipalvelujen tavaratalo -idea jäi varsin problemaattiseksi brittisovel- lutuksessaan. Se siirrettiin kuitenkin Pohjoismaihin. Uusliberalismin puolesta puhuvat brittiasiantuntijat, usein virkamiehet, kävivät Helsingissä valtion kutsumina levittämässä ideaa valmistelevien ja päättävien tahojen keskuuteen. Sama ilmiö on toistunut nyt myöhemmin pohdittaessa koronapandemian jälkeistä aikaa. Halutaan tietää, miten angloamerikkalaisen uusliberalistisen maailman asiantuntijat aikovat selviytyä taloudellisista kysymyksistä ja miten nämä nyt määrittävät taloudellisen strategian suunnan. Brittien sijasta pandemian aikana Suomessa turvaudutaan amerikkalaisiin taloustutkijoihin brittien erottua EU:sta.

\section{BIG SOCIETY - LAAJENEVA UUSLIBERALISMI}

Vuonna 2010 brittihallitus vaihtui konservatiivien ja liberaalidemokraattien yhteishallitukseksi. Se alkoi harjoittaa Big Society -politiikkaa. Politiikan muututtua aloin seurata uutta suuntausta (Koskiaho 2014). Uusi politiikka otti uusliberalistisesta aihekokoelmasta etualalle individualistisen vapauden sekä yksilön velvollisuudet ja oikeudet toimia itse talouteen liittyvissä asioissa, kuten sosiaalipolitiikassa.

Agendalla oli kansalaisten toiminnan muuttaminen, ei enää niinkään taloussektorin. Tarkoituksena oli vähentää valtion osuutta ja velvollisuuksia kansalaisten elämän kannattelussa. Keskusteluun nostettiin kansalaisyhteiskunnallisten organisaatioiden velvollisuus ottaa vastuulleen julkisen vallan luovuttamia tehtäviä. Sosiaalisen kysymyksen yksityistäminen ei kohdistuisi niinkään yksityisiin yrityksiin vaan kansalaisjärjestöihin, vanhoihin 
ja uusiin, sekä paikallisiin kansalaisten vapaamuotoisiin yhteenliittymiin ja itse kansalaisiin. Kansalaisyhteiskunnan voimistamisen tueksi valtio kustantaisi aluksi organisaatioita, joiden tehtävänä oli kansalaisten ja näiden yhteenliittymisten voimaannuttaminen nimenomaan taloudellisissa asioissa. Parin vuoden kuluttua toiminta alkaisi pyörïä niin rahoittajan kuin kohteenkin osalta omin voimin ilman yhteiskunnan tukea. Päästäisiin uusliberalistiseen tavoitteeseen taloudellisesti voimaantuneista yksilöistä ja yhteiskunnasta, joka toimii kuluttaen mahdollisimman vähän julkisia varoja. Päädyttäisiin kansalaistoimijoiden suureen yhteiskuntaan (Big Society), jossa eri kumppanit hoitavat sosiaalista kysymystä.

Aloin seurata systemaattisesti politiikan toimia, muuttuvaa yhteiskuntaa ja sen haluttavaa monimuotoistumista. Uusi toiminta kohdistui erityisesti sosiaalipolitiikan purkamiseen julkisessa hallinnossa ja toimintojen siirtämiseen paikalliselle tasolle ympäri maata. Asuinalueet tulivat tärkeiksi. Lakeja muutettiin pikavauhtia. Tarkoituksena oli luoda uusi toimiva kansalaisyhteiskunta, joka vastaa uusliberalistisiin talouden haasteisiin eikä vastusta talouden sujumista. Skotit katsoivat tätä politiikkaa sivusta eivätkä seuranneet suoraan muun maan ratkaisuja. He säätivät omat lakinsa ja suunnittelivat omat toimenpiteensä, jotka eivät olleet niin radikaaleja kuin Englannissa ja Walesissa.

Pääministeri David Cameron, joka johti uutta politiikkaa, ei juurikaan puuttunut usein toistuvissa poliittisissa selonteoissaan politiikkansa suhteeseen yksityiseen talouteen tai suuryrityksiin, jotka olivat nopeasti ottaneet muun muassa ikääntyneiden palvelut ja lastensijoituspalvelut haltuunsa yksityistämisprosessissa. Tämä suurten kustannuserien toiminta jatkui entisellään koko Big Society -politiikan olennaisimman ajan 2010-2015. Valtio maksoi, ja yksityiset suuryritykset toimivat palveluntuottajina muutaman vuoden sopimuksin Varsin nopeasti hallitus totesi, että palvelujen valvonta ja informaatiopalvelu tulevat liian kalliiksi. Palveluntarjoajan omavalvonnassa ja omassa informaatiossa - joihin siirryttiin - ei ollut enää vertailun mahdollisuutta. Raha ratkaisi ja yksityisen talouden toimintavapaus kasvoi. Uusliberalismi eteni ja entinen kolmannen tien sosiaalinen ulottuvuus oli jo kutistettu minimiin.

Kansalaisyhteiskunnan voimistaminen tapahtui paremmin toimeentulevien asuinalueilla ja paikallisyhteisöissä, koska koulutetut ja valta-asemissa jo muutenkin olevat osasivat käyttää muita paremmin hyväkseen hallituksen tarjoamia etuja ja mahdollisuuksia. Labourpuolueen hallitsemassa Manchesterissä kritisoitiin voimakkaasti Big Society - politiikkaa.Tutkimuksin todettiin, että kansalaisten osallisuus uusien osallistumismahdollisuuksien käyttämiseen jäi entisillä teollisuusalueilla heikoksi. Kansalaisyhteiskunnan voimistamiseksi suunnattu alkuvuosien rahallinen tukeminen loppui ja siirtyi organisaatioiden omalle taloudelliselle vastuulle. Tämä vähensi kiinnostusta kansalaistoiminnan laajentamiseen. Ehkä Manchesterin yliopiston kuuluisa sosiaalipolitiikkaoppiainekin lakkautettiin sen harjoittaman liiallisen kriittisen arviointitutkimuksen vuoksi.

Vuonna 2007 alkanut finanssikriisi lisäsi kritiikkiä uusliberalismia kohtaan 
erityisesti globaalilla tasolla. Huomio alkoi enenevästi siirtyä makohtaisesta kiinnostuksesta kansainvälisiin ja nimenomaan finansialisaatiokysymyksiin. Suhtautuminen julkisen velan ottoon myös EU:ssa väljeni. Julkisia menoja alettiin enenevästi paikata velkarahalla myös niissä maissa, jotka olivat suhtautuneet pidättäytyvästi velkatason nostoon, kuten Suomessa. Velkaa alettiin maksaa aina uudella velalla, mikä oli uutta keskuspankkitasolla siinä laajuudessa, missä ekonomistit alkoivat suosia tätä politiikkaa. Uusliberalismista tuli entistä enemmän finansialisaatiopolitiikkaa kansainvälisellä tasolla. Kilpailun, markkinoistamisen, yksityistämisen ja taloudellisen individualismin uusliberalismista tuli finansialisaation innovointipolitiikkaa. Sosiaalipolitiikan uudistukset tehtiin velkarahalla maasta toiseen. Politiikan takana olivat kansainväliset järjestöt ja Euroopassa EU. Big Society -idean uupuessa brittiyhteiskunnassa uusliberalismin kiinnostus oli siirtynyt maakohtaisuudesta enemmän globaalille ja kansainväliselle finanssimaailman tasolle.

\section{KOHTI BREXITIÄ JA SEN JÄLKEISTÄ ELÄMÄÄ - HAJOAVA UUSLIBERALISMI}

En tämänkään jälkeen malttanut jättää brittien tien seuraamista. Olen siirtynyt ihmettelemään, mistä tässä uusliberalismissa yleensä oikein on ja on ollut kyse. Mikä on uusliberalismin tulevaisuus eurooppalaisesta näkökulmasta katsoen?

Brittikehitys sai kolauksen Brexit-äänestyksessä. Big Society oikeastaan "sai potkut" ja pääministerin oli erottava epämääräisen politiikan seurauksena.
Vuoden 2015 jälkeen brittien tie johti kansalaisten yhä suurempaan tyytymättömyyteen myös maan eri alueiden epätasa-arvoista kehitystä kohtaan. Populismikin nosti päätään. Erityisesti vanhojen kalastus- ja satama-alueiden väestö koki tulevansa syrjäytetyksi. Näille alueille Itä-Euroopan sosialismin romahduksen jälkeen 1990-luvulla muuttaneita itäeurooppalaisia ei suvaittu, vaikka juuri nämä työntekijät ja pienyrittäjät pitivät pystyssä muuten romahduksen vaarassa olleita alueen elinkeinoja (Koskiaho 2017).

Brexit-äänestyksen 2016 tulos, eroaminen EU:sta, oli erityisesti vanhojen elinkeinojen alueiden väestön äänestämisen tulosta samaan tapaan kuin USA:n protestipresidentinvaalien tulos presidentti Trumpia valittaessa samana vuonna. Uusliberaalin politiikan kahden ydinalueen, USA:n ja Ison-Britannian, joutuminen yhteiskunnalliseen käymistilaan lienee osaltaan vaikuttanut siihen, että arvioinnit uusliberalismin kuolemasta lisääntyivät.

On mielenkiintoista, että molemmat uusliberalismin konkreettisen toteuttamisen angloamerikkalaiset johtomaat ovat suunnilleen samaan aikaan myös päätyneet poliittiseen ja yhteiskunnalliseen katastrofiin, joksi syntynyttä tilannetta voisi luonnehtia (Kofas 2021). Taustalla on yhteiskunnan jäsenten epätasa-arvon tunteen voimistuminen (esim. Milanovic 2019). Uusliberalismin toteuttaminen alkoi, kun teollinen vallankumous päättyi näissä maissa teolliseen restrukturaatioon. Varsinkin USA:ssa sitä ei osattu hoitaa, minkä voi tänä päivänä nähdä entisten suurten teollisuuskaupunkien kehittämisen hylkäämisenä ja raunioitumisena USA:ssa 
sekä työttömien asukkaitten aseman kurjistumisena. Brittiyhteiskunnassa teollisuuskaupunkeja on yritetty uudistaa, kuten Manchesterit-projektissakin selvitettiin. USA:ssa myös maanviljely on jäänyt politiikan laidalle, koska se ei ole uusliberalismin ydinaiheita. Vastaavasti Isossa-Britanniassa viljelyelinkeinot, kalastus sekä vene- ja laivaliikenteeseen liittyvät kuljetuselinkeinot ovat kärsineet. Myös tästä on aiheutunut elintason alenemiseen liittyvää katkeruutta erityisesti viljelijä- ja kalastajaväestön keskuudessa. Katkeruuteen liittyvä populismi näyttääkin seuranneen tiiviisti uusliberalismin vanhenemisen kantapäillä (Koskiaho 2017).

Brittien Brexit on toteutettu vuoden 2021 alusta lähtien, ja myös uusi presidentti on aloittanut toimikautensa USA:ssa. Molempien maiden tutkijat ovat pohtineet tulevaisuutta. Voiko se vielä rakentua uusliberalismin jollekin uudelle muunnokselle, vai tarvitaanko ja kaivataanko uusia arvoja individualistisen ja kilpailuun perustuvan markkina-ajattelun sijaan? Vastausta on haettu menneestä eli keynesiläisyydestä ja marxilaisuudesta sekä näiden uudistamisesta. Yhteisyys ja yhteisöllisyys näyttävät taas olevan esillä eikä kansalaisyhteiskunnan vetovoimaisuuttakaan ole unohdettu. Esikuviksi marssitetaan vasemmistolaisia tai vasemmistoliberaaleja tutkijoita ja heidän sanomaansa tulevaisuuden rakentamisesta. Uuden sanoman tuojaksi on nostettu myös naistutkija, italialaisamerikkalainen Mariana Mazzucato. Hänen mukaansa keynesiläisen politiikan aikakauden hyveisiin viittaaminen tulevaisuuden toivottavina ominaisuuksina johtaa joko uusliberalismin hylkäämiseen tai sen muuttumiseen taas uuteen muotoon
(Mazzucato 2015). Uusliberalismia, jota on rakennettu 1970-luvun lopulta alkaen, ei kuitenkaan koronapandemian jälkeen tule olemaan, näin useimmat aihepiirin tutkijat uskovat niin USA:ssa kuin Brittein saarillakin.

\section{ONKO UUSLIBERALISMILLA MONTA HENKEÄ VAI ONKO SE JO KUOLEMASSA TAI JOPA KUOLLUT?}

Eurooppalaisten tutkijoiden piirissä on finanssikriisin jälkeen varsin suuri joukko, joka on vakuuttunut uusliberalistisen kauden päättymisestä. Koronakeväänä 2020 netti pursui näistä kommenteista. Angloamerikkalaiset tutkijat ovat luonnehtineet tilannetta ainakin seuraavin näkökohdin (Birch \& Mykhenenko 2010; Dean 2019; Jessop 2017 ja 2019; Katz 2015; Peck \& Theodore 2019; Zwick 2015):

\section{Uusliberalismi on tuhonnut elävät mark-} kinat. Taloudesta ovat kadonneet todelliset innovaatiot. Koko yhteiskunnassa on tapahtunut jäykistymistä. Ei ole enää kykyä tehdä isoja asioita. Uusliberalismi on tuhonnut itse itseään eikä koko kapitalismilla ole enää kykyä uusintaa itseään. Syytä voi hakea markkinoistumisen teoriasta ja markkinoista, ei itse makrotaloustieteestä. Luovan tuhon kyky on vähentynyt erityisesti uusliberalismiin liittyvän finansialisaation lisääntymisen myötä tällä vuosituhannella.

2. On myös kasvatettu markkinabyrokratioita innovaatioiden vähenemisen myötä, vaikka uusliberalismi alkuaan hyökkäsi juuri keynesiläisen hyvinvointivaltion byrokratisoitumisen kimppuun. Uusi byrokratisoituminen liittyy kritiikin 
mukaan stabiiliin uuteen luokkajärjestelmään ja siihen sisältyvään taloudelliseen kontrolliin. Stabilisoituminen viittaa siihen, ettei uusliberalismi kykene radikaaleihin visioihin eikä todelliseen yhteiskunnalliseen tai teknologiseen muutokseen.

\section{Investoijat eivät ole kiinnostuneita pitkän aikavälin kehityksestä eivätkä sitoutunei- suudesta vaan saalistavat lyhyen aikavälin voittoja. Pyritään vain kustannusten vä- hentämiseen, tehokkuuteen ja riskien minimoimiseen.}

\section{Kokonaisuudessaan uusliberalismia moi-} titaan pintapuolisuudesta. Kuitenkin yksilöiden ja instituutioiden pitää palvella entistä paremmin systeemiä ja sen toiveita, todetaan. Samasta seikasta saksalainen sosiologi Max Weber aikoinaan 1940-luvulla arvosteli oman aikansa yhteiskuntaa. Uusliberalismin mukaan toimittaessa vaaditaan muotojen täyttämistä ja jatkuvaa toiminnan raportointia. Tämä toiminta on levinnyt yksityisestä taloudesta koko yhteiskunnan toimintoihin, myös yliopistolaitokseen, entiseen vapaan tieteen mekkaan. Siinä kilpaillaan rahoittajien suosiosta, myydään ideoita rahoittajille mutta ei ylletä kumouksellisen uusiin tuloksiin, kritisoivat yliopistotutkijat omaa toimintaympäristöään.

Uusliberalismin toiminnasta ja tuloksista on rakennettu varsinaista rappioteoriaa. Toiveet kuolemasta ovat olleet ilmassa jo pitkään. On koko ajan niitäkin, jotka uskovat uusliberalismin muuntautumiskykyyn esimerkkinä kiinalainen kommunismin ja autoritääriseksi luokitellun uusliberalismin nykyinen yhdistelmä. Lännessä odotetaan saatavan aikaiseksi jonkinlainen yhdistelmä keynesiläisistä hyvinvointivaltiollisista ideoista maustettuina uusliberalistisilla aineksilla (Mazzucato \& Penna 2015), kunhan vain ne harvat, jotka pitävät todellista taloudellista valtaa, ymmärtävät asemansa oikein (Acemoglu \& Robinson 2012).

\section{UUSLIBERALISMIN JÄLKEEN}

Saksalainen Gabriele Winker (2015) maalailee uusliberalismin jälkeistä näkökulman vaihtoa, joka johtaa myös hoivan vallankumoukseen. Yhteiskunnan tulee olla solidaarinen eikä hamuta voiton maksimointia. Keskipisteeksi tulevat tarpeet ja huoli. Ihmisiä ei enää saa panna kilpailemaan toistensa kanssa, vaan heidän tulee saada muodostaa yksilöllisen elämänsä yhteisöllisissä puitteissa. Tuttua tekstiä sosiaalipolitiikan historiallisista hyveistä. Myös sveitsiläiset tutkijat korostavat hyvinvointivaltion kriisin aikaa, uusliberalismia, itsestä huolehtimisen ajaksi vastakohtana yhteiskunnan solidariteetille. Uusliberalismi on pakottanut vapauteen solidariteetin ja turvan sijasta (Ludi \& Ruoss 2018). Tuen tarpeessa olevat eivät ole hyötyneet uusliberalismin ajan tarjoamasta ideaalista, yksilön vapaudesta tehdä (taloudellisia) valintoja. Niinpä nyt sitten on aika vedota taas valtioon. Tämän pitäisi uudistua vastaamaan sosiaalisen elämän vaateisiin yhteiskunnallisessa tilanteessa, johon uusliberalismi on yhteiskunnan johtanut.

Bob Jessop (2017) kuvaa brittien uusliberalismin kehitystä, uusliberalisaatiota, orgaaniseksi kriisiksi, joka alkoi jo kauan sitten ja päätyi lopuksi Brexitiin. Brittien sosiaalipolitiikka onkin luonteeltaan suuntautunut enemmän 
alempiin tuloluokkiin, kun se pohjoismaisessa ja keskieurooppalaisessa versiossa on ollut enemmän koko kansan politiikkaa (policy-merkityksessä). Molempia uusliberalisaatio on kohdellut kaltoin. Ehkä nyt pitäisi lähteä taas liikkeelle siitä, mistä toisen maailmansodan jälkeenkin, kansalaisoikeuksista (Herrmann 2019). Ne pitäisi uudessa tilanteessa päivittää ja osittain määritellä uudelleen. Tämä voisi olla tärkeätä sosiaalipolitiikan uuden suuntautumisen kannalta.

\section{KirJallisuUs}

Acemoglu, Daron \& Robinson, James A (2012) Why Nations Fail: The Origins of Power, Property, and Poverty. New York: Crown Business. https://doi. org/10.1355/ae29-2j

Birch, Kean \& Mykhenenko, Vlad (toim.) (2010) The Rise and Fall of Neoliberalism. The Collapse of Economic Order. London \& New York: Zed Books. https:// doi.org/10.5040/9781350223486

Dean Mitchell (2019) Rogue Neolibaralism, Liturgical Power, and Search for a Left Govermentality. South Atlantic Quarterly 118 (2), 325-342. https://doi. org/10.1215/00382876-7381170

Doling, John \& Koskiaho, Briitta \& Virkkala, Seija (toim.) (1994) Rerstructuring in old industrial towns in Finland. University of Tampere, Department of Social Policy and Social Work. Research Reports Serie A. Nr. 6. Tampere.

Herrmann, Peter (2019) The Search for The Future Global Human Rights Agenda. The International Journal of Social Quality 9 (2), 58-66. https://doi. org/10.3167/IJSQ.2019.090205

Jessop, Bob (2019) Autoritarian Neoliberalism: Periodization and Critique. South Atlantic Quarterly 118 (2), 343-361. https://doi.org/10.1215/003828767381182

Jessop, Bob (2017) Die organische Krise des britischen Staates: Was der Brexit bedeutet. Links. http://old.links-netz. de/pdf/T_jessop_brexit.pdf Luettu 15.12.2020.

Kofas, Jon (2021) Post-Trump America: Prospect for American Democracy. Academia Letters, February 2021. Article 231. https://doi.org/10.20935/AL231 Luettu 10.2.2021.

Koskiaho, Briitta (1978) Pispalan toimintatutkimus. Teoreettisia ja käytännöllisiä lähtökohtia. Pispala-projekti 2. Tampereen yliopisto. Sosiaalipolitiikan laitos. Tutkimuksia 14. Tampere.

Koskiaho, Briitta (2008) Hyvinvointipalvelujen tavaratalossa. Palvelutalous ja sosiaalipolitiikka Englannissa, Ruotsissa ja Suomessa. Tampere:Vastapaino.

Koskiaho, Briitta (2014) Kumppanuuden sosiaalipolitiikkaa etsimässä. Setlementtijulkaisuja 32. Tallinn: United Press Global.

Koskiaho, Briitta (2017) Pääministeri Mayn Shared Society -julistus IsossaBritanniassa. Tampereen yliopisto. Alusta! 10.1.2017. http://alusta.uta.fi/artikkelit/2017/01/10/paeaeministeri-maynshared-society--julistus-isossa-britanniassa.html Luettu 10.10.2017.

Koskiaho, Briitta (2018) Ordoliberalismin sosiaalihumaani suuntaus odottaa uutta valtakauttaan. Tieteessä tapahtuu 4 , 21-28.

Koskiaho, Briitta \& Nurmi, Johanna \& Virtanen, Petri (1999) Kansalaisen sosiaalipolitiikka. Juva:WSOY.

Kotz, David M. (2015) The Rise and Fall of Neoliberal Capitalism. Harvard: Harvard University Press. https://doi. org/10.4159/harvard.9780674735880

Mazzucato, Mariana (2015) To Market Fixing to Market Creating:A Framework for Economic Policy. SPRU Working Paper Series 2015-25. University of Sussex. https://doi.org/10.2139/ssrn.2744593 Luettu 2.1.2021.

Mazzucato, Mariana \& Penna, Caetano C.R. (2015) Mission-Oriented Finance for Innovation: New Ideas for Investment-Led Growth. London \& New York: Rowman \& Littlefield International.

Milanovic,Branco (2019) Capitalism,Alone. The Future of the System That Rules the World. Cambridge MA:The Belknap Press of Harvard University. https://doi. 
org/10.4159/9780674242852

Peck, Jamie \& Theodore, Nick (2019) Still Neoliberalism? South Atlantic Quarterly 118 (2), 245-265. https://doi. org/10.1215/00382876-7381122

Slobodian, Quinn \& Plewne, Dieter \& Mirowski, Philip (toim.) (2020) Nine Lives of Neoliberalism. London and New York: Verso. versobooks.com. https:// doi.org/10.1080/19460171.2021.19361 05 Luettu 15.12.2020.
Social Enterprise UK. https://www.socialenterprise.org.uk/ Luettu 2.2.2021.

Zwick, Detlev (2015) No Longer Enough?: Creative Derstruction, Innovation and Ossification of Neoliberal Capitalism. Schurlich School of Business. York University. Canada. Journal of Marketing Management 34 (11), 1-19. https://doi. org/10.1080/0267257X.2018.1536076 